\title{
JATIDIRI MANUSIA BERDASARKAN FILSAFAT TINDAKAN \\ HANNAH ARENDT PERSPEKTIF FILSAFAT MANUSIA: RELEVANSI DENGAN PELANGGARAN HAM TAHUN 1965-1966 DI INDONESIA
}

\section{Astrid Veranita Indah}

Mahasiswa Program Doktor Filsafat, Universitas Gadjah Mada

Email: avindah@gmail.com

\section{Abstrak}

Pelanggaran HAM merupakan persoalan ensensial dalam kehidupan manusia. Persoalan tersebut menimbulkan berbagai persoalan baru, diantaranya adalah trauma yang diderita korban dan rasa bersalah pelaku pelanggaran. Beberapa kasus pelanggaran HAM, seringkali dapat diselesaikan dengan peradilan konstitusi. Kasus yang lain tidak dapat diselesaikan dengan undang-undang yang telah dibentuk. Kasus seperti itu, diperlukan penyelesaian dengan sudut pandang yang lain. Penyelesaian tersebut bisa dengan memahami struktur dasar jatidiri manusia, berdasarkan filsafat tindakan Hannah Arendt. Penelitian ini merupakan penelitian kualitatif dengan menekankan studi pustaka dalam memperoleh data. Metode yang digunakan dalam penelitian ini antara lain: metode hermeneutika, dan metode heuristika. Objek formal penelitian ini adalah jatidiri manusia sebagai persoalan filsafat manusia. Jatidiri manusia memiliki unsur-unsur, yaitu: kepribadian manusia, identitas diri manusia, dan keunikan dalam sosialitas manusia. Hasil penelitian meliputi paparan tentang filsafat tindakan manusia, sebagai aktivitas ultim dalam kehidupan aktif manusia. Manusia sebagai pribadi, yang terdiri dari badan dan jiwa; jiwa dan pikiran. Identitas diri dipahami bukan hanya masa sekarang, namun juga masa lalu dan proyeksinya akan masa depan. Manusia berkembang tanpa henti dalam historisitas waktu, sehingga masing-masing pribadi memiliki keunikan dari yang lain. Keunikan tersebut mewarnai keberbedaan dalam pluralitas kehidupan, yang diharapkan mampu menjaga terciptanya persahabatan dalam sebuah komunitas. Filsafat Arendt telah berhasil menjawab persoalan pelanggaran HAM pada masa di bawah kekuasaan Nazi. Analisis Arendt terhadap persoalan tersebut menekankan pada kepribadian manusia yang memiliki kesadaran berpikir dalam menghadapi situasi yang cenderung otoriter. Analisis lain adalah adanya kemampuan manusia mengampuni, berjanji serta memba- 
ngun persahabatan. Hal tersebut menginspirasi untuk menjawab persoalan pelanggaran HAM tahun 1965-1966 di Indonesia. Pemahaman berdasarkan kesadaran berpikir, ampunan, janji dan persahabatan akan memutus siklus dendam, memulihkan ingatan sosial, dan menjamin terciptanya hak asasi setiap warga negara.

Kata kunci: pelanggaran HAM, jatidiri manusia, filsafat tindakan Hannah Arendt.

\section{Abstract}

The essential problem of human rights violation is a matter of human life. The issue raises many new problems, including the trauma suffered by victims and guilty feelings experienced by perpetrators. Some cases of human rights violation, can often be resolved by the constitutional court. Other cases cannot be solved by laws and regulations that have been established. In such cases, it requires an accomplishment by using another point of view, for example, by understanding the basic structure of human person, based on Hannah Arendt's philosophy of action. This research is a qualitative research with emphasises library research in obtaining datas. Methods used in this study are: hermeneutics, and heuristics. The formal object is human person that is part of philosophy of human. Theory of human person which is categorized into three parts, namely: the personality of human, selfidentity of human, and the uniqueness in the sociality of human. The result of this research is an exposure of the philosophy of human action, as an ultimate activity in the vita activa. Human beings as individuals, are body and soul; soul and mind. Self identity is understood not only as the present, but also the past and the projections of the future. Human beings develop continuously in the historicity of the time, so that each individual is unique from the others. This uniqueness colors the difference in plurality of life which is expected to keep the friendship in a community. Arendt's philosophy has been successfully answered the problem for human rights violation during the under Nazi rule. Arendt's analysis of the problem for the emphasis on the human personality-conscious thinking in a situation that tends to be authoritarian. Another analysis is the human ability to forgive, promise and build friendship. It is inspire to answer the problem for human rights violation at Indonesia upon 1965-1966. Understanding based on consciousness thinking, forgiveness, promise and friendship will break the cycle of revenge, restore social memory, and ensure the creation of rights of every citizen.

Keywords: human rights, human person, Hannah Arendt's philosophy of action 


\section{PENDAHULUAN}

Berbagai tragedi kemanusiaan berlangsung di dalam kehidupan manusia. Tragedi kemanusiaan di masa lalu yang disertai oleh kekerasan antara sesama manusia menorehkan ingatan sosial yang berkembang di dalam masyarakat. Kekerasan antar sesama berujung pada pelanggaran hak asasi manusia. Setiap pelanggaran HAM menuntut upaya peradilan dan perdamaian, di mana amnesti dan rekonsiliasi menjadi pilihan terhadap penyelesaian tragedi berdarah dalam sejarah manusia. Peristiwa berdarah yang terjadi di Indonesia pada tahun 1965-1966 menjadi bukti pentingnya penyelesaian secara hukum. Penyelesaian tragedi tahun 1965-1966 ternyata belum dilakukan dengan maksimal sesuai dengan prinsip hukum. Proses peradilan, amnesti maupun rekonsiliasi hanya menjadi wacana yang berkembang di Indonesia.

Amnesti dan rekonsiliasi sangat penting untuk meninjau kembali pelanggaran HAM yang terjadi pada masa lalu, sebagai upaya pemerintah dalam menegakkan keadilan dan perdamaian di Indonesia. Korban, keluarga korban atau pelaku akan sangat sulit menjalani kehidupan yang damai dalam masyarakat, tanpa proses penegakan hukum. Amnesti dan rekonsiliasi di dalam pelaksanaannya, seringkali terhambat oleh beberapa kelompok, baik yang mendukung atau menolak. Hal ini berakibat pada ketidakpastian menggelar proses peradilan dan memberlakukan amnesti atau rekonsiliasi.

Amnesti adalah suatu tindakan untuk melupakan sebuah kejahatan. Seseorang yang telah diberi jaminan amnesti tidak akan dituntut atas suatu kejahatan yang tercakup dalam amnesti. Efek hukum sebuah amnesti ialah memandang sebuah kejahatan seakan tak pernah terjadi dan menghapus kejahatan seseorang dan tanggungjawab sosial. Sebab gugatan pengadilan tidak akan dilakukan. Amnesti dijamin baik secara kolektif (amnesti umum) maupun atas permintaan perorangan (Ardiastro, 2007: 163).

Rekonsiliasi adalah pengungkapan kebenaran dan keadilan, yang biasanya ada pemberian grasi dan kompensasi dari pemerintah 
terhadap pihak yang bersalah. Proses rekonsiliasi di Afrika Selatan misalnya berlaku bebas dari hukuman bagi pelaku, sehingga biasanya keluarga korban sulit menerima, dan kemudian akan menciptakan permasalahan ketidakadilan.

Untuk mengatasi dampak pelanggaran HAM, tidak ada aturan hukum yang mampu menyelesaikannya dengan sempurna, termasuk konsep amnesti dan rekonsiliasi yang disepakati dunia International. Kisah tragedi kemanusiaan tidak hanya berhenti pada apa yang terjadi, namun juga menghasilkan bermacam-macam akibat dari tragedi tersebut karena sistem peradilan tidak mampu mengobati dendam dan rasa bersalah. Kedamaian tidak mampu dilaksanakan hanya dalam tataran sistem sosial, namun memerlukan upaya perubahan sikap dalam setiap diri manusia.

Upaya perubahan yang berkaitan dengan sikap manusia senantiasa diuji dalam kemajuan zaman. Sikap manusia bukan sepenuhnya terbentuk berdasarkan sebuah sistem yang kaku seperti dalam birokrasi pemerintahan. Sikap manusia teraktualisasi di dalam proses pengembangan daya kreativitas di dalam diri sendiri serta interaksinya dengan masyarakat sekitar. Proses pengembangan daya kreativitas dalam diri manusia merupakan langkah awal bagaimana manusia membentuk jatidirinya. Hal ini letak urgensi pembentukan jatidiri manusia, jika dibenturkan dengan tragedi kemanusiaan pada masa lalu, agar tercipta sebuah kedamaian dalam interaksinya dengan masyarakat sekitar. Kedamaian mampu diwujudkan oleh setiap individu dengan membentuk dan memahami jatidiri manusia.

Pemahaman terhadap jatidiri manusia sangat relevan jika kita belajar dari analisis Hannah Arendt. Penulis berpandangan bahwa pertama, Arendt mampu menjawab akibat dari pelanggaran HAM yang menewaskan beribu-ribu orang Yahudi di bawah kekuasaan Nazi. Kedua, kemampuan Arendt sebagai salah satu orang Yahudi yang mampu memaafkan perbuatan para Nazi setelah kekuasaan Hitler berakhir. Ketiga, pemaparan Arendt terhadap pengadilan Nuremberg dan penilaian Arendt bahwa telah terjadi kejahatan banal pada kasus Eichmann. Ke- 
empat, tulisan Arendt banyak memaparkan pentingnya menggunakan kemampuan mental untuk mengenali martabat manusia.

Penulis memaparkan empat alasan di atas untuk menganalis bahwa dengan adanya pelanggaran HAM pada masa lalu, tidak kemudian menjadikan jatidiri bangsa Indonesia tidak seimbang. Jatidiri manusia tetap utuh, meskipun terdapat banyak kesalahan pada masa lalu. Penulis berharap bahwa konsep jatidiri manusia dapat digunakan sebagai alternatif damai dalam mengatasi dendam masa lalu serta memberikan perubahan yang lebih baik dalam masyarakat. Jatidiri manusia bukan hanya membahas pengampunan terhadap permasalahan masa lalu, namun juga sebuah harapan baru bagi masa depan. Pemahaman tentang jatidiri manusia diharapkan mampu mengembangkan daya kreativitas masing-masing individu dalam menyelesaikan persoalan, serta menghindari tindak kejahatan. Pemahaman jatidiri ini dapat kita pelajari dari pemikiran Arendt bahwa bukan hanya Tuhan, namun manusia juga memiliki kemampuan memaafkan.

Penulis sebelumnya telah memaparkan beberapa persoalan pelanggaran HAM, yang tidak mampu diselesaikan dalam ranah hukum, sehingga memerlukan pendekatan lain, yaitu dengan pembentukan jatidiri manusia. Permasalahan yang akan dikaji lebih lanjut dalam penelitian ini adalah: 1). Apa hakikat jatidiri manusia dalam filsafat tindakan Arendt perspektif; 2) filsafat manusia? 3) Bagaimana relevansi jatidiri manusia dalam filsafat tindakan Arendt perspektif filsafat manusia, dengan pelanggaran HAM tahun 1965-1966 di Indonesia?

\section{JATIDIRI MANUSIA}

Pengertian jatidiri manusia merujuk pada buku Hardono Hadi yang berjudul A Whitehedian Reflection on The Human Person. Pemikiran Hardono Hadi tentang jatidiri manusia digunakan penulis dengan alasan sebagai berikut: pertama, jatidiri manusia dalam pemikiran Hardono Hadi memaparkan pemahaman yang mendalam tentang unsur-unsur jatidiri manusia yang mampu direlevansikan dengan filsafat Barat, yaitu filsafat organisme Whitehead. Penulis berasumsi bahwa unsur-unsur jatidiri manusia dalam tulisan Hardono Hadi, dapat dire- 
levansikan dengan filsafat Arendt. Kedua, menurut Hadi (1996: 18) bahwa jatidiri merupakan persoalan sepanjang zaman, dengan memahami jatidiri maka manusia diharapkan bersikap kritis terhadap pengalaman yang dihadapi. Penulis berasumsi bahwa alasan kedua ini mampu digunakan untuk menganalisis persoalan pelanggaran HAM di Indonesia.

Penulis telah memaparkan alasan pemilihan konsep jatidiri manusia, terutama dirujuk dari pandangan Hardono Hadi. Pengertian jatidiri manusia dalam pandangan Hardono Hadi, jika diterjemahkan ke dalam bahasa Inggris, menjadi Human Person. Pemilihan kata 'jatidiri' menjadi 'human person' karena jatidiri memuat tiga aspek, yaitu pribadi, identitas diri dan keunikan diri. Jatidiri manusia diartikan sebagai $h u-$ man person, bukan self atau identity. Hal ini berarti bahwa jatidiri manusia mendalami hakikat manusia secara utuh, bukan hanya berkaitan dengan diri, atau identitas.

Kata persona juga dijelaskan oleh Sihotang. Persona secara etimologis berasal dari bahasa Yunani, yang artinya topeng. Konon dalam tradisi seni drama masyarakat Yunani, para pemain sandiwara harus mengenakan topeng ketika memainkan peran tokoh tertentu. Melalui topeng sang aktor/aktris menghadirkan watak tokoh yang dimainkan. Topeng sesungguhnya dipakai sebagai media untuk menghadirkan pribadi seseorang di hadapan penonton (Sihotang, 2009: 34). Persona dalam perkembangannya, tidak lagi dimengerti sebagai sebuah topeng, melainkan kualitas-kualitas pribadi yang ada dalam diri seseorang. Arti persona tidak lagi menunjuk pada topeng, melainkan pada makna yang ada di baliknya, yakni jatidiri (Sihotang, 2009:35).

Jatidiri manusia lebih tepat disebut human person, karena menunjuk pada hakikat manusia atau martabat manusia. Jatidiri manusia mengandaikan adanya pribadi manusia yang unik. Keunikan manusia karena manusia terdiri dari badan jiwa. Manusia mampu menentukan pilihannya sendiri dengan jiwa dan pikirannya. Manusia sebagai pribadi yang unik sekaligus memiliki identitas diri di dalam lingkungannya, yang juga dihadapkan pada persoalan-persoalan sebagai manusia. 


\section{JATIDIRI MANUSIA}

\section{SEBAGAI PERSOALAN FILSAFAT MANUSIA}

Tujuan filsafat manusia adalah mendalami hakikat manusia. Manusia dengan mendalami esensi manusia, maka akan menemukan jatidirinya. Menurut Hadi (1996: 25) bahwa jatidiri manusia mempunyai pengertian ganda. Pertama, jatidiri manusia mengandaikan adanya kesatuan yang utuh di dalam diri manusia. kesatuan ini begitu mutlak sehingga terasa begitu jelas ketunggalan di dalam dirinya sendiri yang tidak bisa dibagi-bagi. Kedua, manusia yang terdiri dari bagian-bagian dan aspek-aspek yang begitu kaya. Manusia terdiri dari badan dan jiwa, yang masing-masing mempunyai kegiatan, kemampuan, dan gaya, serta perkembangannya sendiri. Jatidiri manusia memuat aspekaspek unitas kompleksitas, aspek historisitas dan aspek sosialitas.

Aspek-aspek di atas merupakan persoalan-persoalan filsafat manusia, yang sekaligus unsur-unsur yang memuat jatidiri manusia. Aspek unitas-kompleksitas memuat persoalan badan dan jiwa manusia. Aspek historisitas dalam dinamika sejarah, dari masa lalu, masa sekarang dan masa depan. Aspek sosialitas, di mana manusia yang memiliki keunikan bersosialisasi dengan masyarakat. Beberapa aspek tersebut, akan dijelaskan sebagai berikut.

Pertama, badan dan jiwa manusia. Persoalan pertama tentang jatidiri manusia adalah adanya aspek unitas sekaligus kompleksitas dalam diri manusia. Hal ini berati manusia terdiri dari dua unsur, yaitu badan dan jiwa. Hadi (1996: 25) menjelaskan bahwa berbicara tentang jatidiri manusia atau martabat manusia sebagai seorang manusia yang utuh mempuyai pengertian ganda. Jatidiri mengandaikan adanya kesatuan yang utuh di dalam diri manusia. Kesatuan ini begitu mutlak sehingga terasa begitu jelas ketunggalan di dalam dirinya sendiri yang tidak bisa dibagi-bagi.

Manusia di lain pihak, juga menyadari diri kita meskipun sebagai satu kesatuan yang utuh, namun diri jelas terdiri dari bagian-bagian dan aspek-aspek yang begitu kaya. Manusia terdiri dari badan dan jiwa, yang masing-masing mempunyai kegiatan, kemampuan, dan gaya serta perkembangannya (Hadi, 1996: 25). Manusia yang terdiri dari ba- 
dan dan jiwa disadari oleh Plato. Pemikiran Plato berkaitan dengan badan dan jiwa dipaparkan Wibowo (2009: 191) bahwa badan merupakan penyempurnaan seperti dalam Timaios 44E. Plato menjelaskan bahwa tubuh adalah instrumen bagi kepala manusia. dikisahkan bahwa para asisten Demiougos meletakkan jiwa immortal (bagian paling illahi) ke dalam kepala, dan supaya kepala ini bisa berpindah-pindah dengan enak (tidak harus bergulung-gulung dengan resiko kotor atau kejeblos di lubang), para dewa lalu memberikan kendaraan atau instrumen. Plato menjelaskan bahwa sama sebagaimana dalam tubuh ada relasi instrumental antara kelapa dengan bagian tubuh lainnya, hal yang sama juga bisa ditemukan antara jiwa dengan tubuhnya.

Badan/tubuh bukan selalu dimaknai lebih rendah daripada jiwa. Tubuh bahkan digunakan atau menjadi alat bagi jiwa untuk mencapai kesempurnaan yaitu kepada dunia ide. Untuk mencapai kesempurnaan perlu adanya tindakan merawat jiwa. Menurut Cahyadi (2008: 1920) bahwa konsep merawat jiwa tampak pada filsafat Plato dalam tiga dimensi terpadu, antara lain: pertama, dimensi yang terkait dengan keadilan seperti ungkapan Sokrates bahwa "lebih baik menderita ketidakadilan daripada berbuat tidak adil." Kedua, merawat jiwa dengan adalah merawat keutamaan untuk mencapai kebijaksanaan dan kebenaran atau harmoni antara kekuasaan dan kebebasan. Ketiga, merawat jiwa dengan sesuatu yang tak berhingga, imortalitas, kekekalan yaitu dengan pengetahuan.

Kedua, historisitas manusia. Persoalan kedua jatidiri manusia adalah adanya aspek historisitas. Historisitas atau kesejarahan menyatakan manusia senantiasa berubah dalam kehidupan. Menurut Hadi bahwa aspek historisitas yang mencakup persamaan dan perubahan di dalam proses (Hadi, 1996: 39). Proses historisitas menekankan pentingnya proses kehidupan yang terus-menerus bergulir, tanpa akhir kecuali oleh kematian. Manusia di dalam proses historisitas tidak hanya dinilai dari masa sekarang, namun berkaitan dengan masa lalu dan proyeksi manusia terhadap masa depan. Aspek historisitas di sini menggambarkan pentingnya penilaian yang tidak hanya berhenti pada masa tertentu, namun manusia dinilai dari perubahan di dalam pro- 
ses kehidupan. Kant (1959) dalam Critique of Pure Reason memaparkan bahwa identitas diri tidak dapat divalidasi. Kant dalam Third Paralogism menggambarkan tentang identitas diri dengan mengatakan bahwa "Consciousness of myself in different times is the only formal condition for personality or personal identity." Kant menunjukkan bahwa waktu terwakili oleh 'aku' dan kesadaran dari waktu ke waktu sama sekali tidak membuktikan identitas numerik subjek-ku.

Ketiga, sosialitas manusia. Persoalan ketiga jatidiri manusia adalah aspek sosialitas. Aspek sosialitas manusia yang mempunyai martabat pribadi dengan kebebasannya sehingga, tidak boleh dikorbankan demi kepentingan lain sebagaimana ditekankan oleh Mill; sebagai makhluk sosial yang mempunyai martabatnya berkat hubungan erat dengan masyarakatnya sebagaimana ditekankan oleh Dewey; sebagai pelaku yang menyadari maksud tindakannya, sebagaimana ditekankan oleh Mcmurray (Hadi, 1996:39).

Mill dalam On Liberty (2005: 17) menjelaskan bagaimana hubungan masyarakat dengan individu, bahwa satu-satunya tujuan yang membenarkan umat manusia baik secara individual maupun kolektif untuk campur tangan dalam kebebasan bertindak setiap anggotanya adalah demi perlindungan diri sendiri. Hal ini berarti bahwa individu diberikan kebebasan mutlak sejauh hanya membuat dirinya bahagia dan tidak merugikan orang lain.

Konsep manusia sebagai makhluk sosial dalam pemikiran Macmurray lebih dipengaruhi pada lingkungan sekitar, namun tidak semua interaksi bersifat personal. Hal ini dijelaskan oleh Mcmurray (1961: 211) bahwa:

We need one another to be ourselves. This complete and unlimited dependence of each of us upon the others is the central and crucial fact of personal existence. Individual independence is an illusion; and the independent individual, the isolated self, is a nonentity.

Pernyataan Macmurray di atas menunjukkan bahwa individualitas dianggap non-entity, sehingga manusia diharuskan berhubungan dengan manusia yang lain sebagai bagian dari kehidupannya. Hubungan 
antarmanusia di sini berdasarkan pada persahabatan dan cinta. Hal ini sekaligus menolak adanya pemikiran hubungan antar manusia yang saling mendominasi satu sama lain. Pribadi yang bebas adalah pribadi yang berhubungan satu sama lain dengan persahabatan dan cinta, bukan dengan ketakutan.

Menurut Hadi (1996: 37-38) bahwa Macmurray menyadari tidak semua interaksi manusia bersifat personal atau pribadi. Hanya kalau manusia memperlakukan sesamanya sebagai pribadi, yaitu sebagai manusia yang mempunyai maksud atau cita-cita, maka interaksi itu bersifat personal. Masyarakat bukanlah melulu kenyataan yang terjadi begitu saja, tetapi melibatkan maksud atau untervensi, maka maksud memainan peranan penting di dalam hubungan manusiawi.

\section{BIOGRAFI HANNAH ARENDT}

Kehidupan filsafat Arendt dimulai dari ketika mulai mempelajari studi klasik dan teologi Kristen di University of Berlin. Saat berusia 18 tahun, ia mulai belajar fenomenologi pada Martin Heidegger di Marburg University. Arendt pergi ke University of Heidelberg pada tahun 1925 untuk belajar bersama filsuf eksistensialis Karl Jaspers. Arendt menulis tesis doktoral tentang konsep cinta St. Augustine di bawah pengawasan Jaspers (Owens, 2010: 40-41). Karya pertama Arendt setelah Disertasi yang berjudul Love and Saint Augustine adalah riset Arendt tentang keluarga Yahudi.

Arendt memulai riset untuk sebuah biografi Rahel Varnhage. Buku ini pertama kali diterbitkan di London tahun 1958 sebagai Rahel Varnhagen: The Life of Jews. Nama keluarga Rahel adalah Lewin, terkenal karena salon intelektualnya. Riset buku ini telah menggiring Arendt menelaah asal-usul antisemitisme dan sejarah yahudi Jerman (Ettinger, 2005: xxxi). Riset tentang salah satu keluarga Yahudi di situ merupakan sebuah riset di mana orang Yahudi berkumpul, membicarakan persoalan mulai dari ekonomi, politik bahkan kehidupan privasi seseorang di sebuah salon. Salon menjadi tempat penting dalam memperkuat komunitas Yahudi di tengah masyarakat yang plural. 
Arendt bekerja untuk organisasi Zionis Jerman pada tahun 1930an. Arendt mempublikasikan apa yang disebut sebagai kejahatan terhadap orang Yahudi dan sempat ditahan untuk pekerjaan ini. Arendt lalu kabur dari Jerman menuju Paris tanpa dokumen sehingga menjadi orang Yahudi yang stateless (tanpa negara). Situasi di Perancis memburuk setelah pecah perang dan di bawah pendudukan Jerman. Arendt ditangkap lagi dan ditahan sebagai orang asing yang menjadi musuh. Arendt melarikan diri bersama suami dan ibunya ke Amerika (Owens, 2010: 41).

Arendt berangkat ke Eropa sebagai utusan Komisi Rekonstruksi Budaya Yahudi pada Maret 1952. Arendt bermaksud menggali unsur totaliter Marxisme untuk bukunya tentang Marx. Arendt mengalihkan fokus perhatian terhadap Marxisme dari totalitarianisme Soviet, setelah sejumlah kritik tertuju pada kegagalan Arendt mempertahankan argumentasinya dalam buku The Origins of Totalitarianism, bahwa Nazisme dan Bolshvisme merupakan ideologi yang dapat disetarakan (Ettinger, 2005: 105). The Origins of Totalitarianism terdiri atas tiga volume, yaitu: Antisemitism, Imprealism, dan Totalitarianism. Asal-usul Totalitarianisme merupakan karya Arendt yang membahas tentang komunitas Yahudi di bawah kekuasaan Nazi.

Pemikiran Arendt yang berbeda dengan komunitas Yahudi pada umumnya menimbulkan berbagai persoalan bagi dirinya. Owens (2010: 41-42) memaparkan bahwa Arendt harus membayar mahal untuk pikiran yang beda dengan opini mengenai Israel. Arendt menunjukkan ambivalensi terhadap seruan kaum Zionis mendirikan tanah air Yahudi eklusif karena solusi bagi problem yahudi akan hanya menghasilkan kategori baru bagi pengungsi. Tulisan Arendt yang berjudul Eichmann in Jerusalem (1968) juga menghasilkan badai kecaman dari kalangan Yahudi. Arendt kehilangan banyak teman, dan hubungannya dengan komunitas Yahudi yang terorganisasi secara efektif menjadi terputus. Eichmann in Jerusalem merupakan laporan jurnalistik Arendt di pengadilan Nuremberg, di mana Arendt membuat penilaian tentang kepribadian Eichmann. 
Penulisan Eichmann in Jerusalem dimulai ketika Arendt bersama Majalah The New Yorker pergi ke Yerusalem untuk meliput pengadilan atas Adolf Eichmann tahun 1961. Birokrat Nazi yang didakwa mengarahkan pengiriman orang Yahudi ke kamp-kamp konsentrasi dalam Perang Dunia II. Artikel itu diperluas dan diterbitkan menjadi buku pada 1963 dengan judul Eichmann in Jerusalem: A Report on the Banality of Evil. Arendt mengamati, Eichmann adalah pejabat biasa-biasa saja dan bukan monster sadis seperti yang banyak orang ingin bayangkan (Owens, 2010: 42). Karya-karya Arendt selanjutnya antara lain: On Revolution, Between Past and Future, Men in Dark Times, Crises of The Republic, The Jews as Pariah, Essays in Understanding, Lectures on Kant's Political Philosophy, Responsibility and Judgment, The Promise of Politics dan, The Jewish Writings.

Karya terakhir Arendt sebelum meninggal adalah The Life of The Mind. Tulisan ini merupakan jawaban atas kesalahpahaman orangorang yang mengira Arendt membela Eichmann. Rencana penulisan The Life of The Mind terdiri dari tiga bagian: Thinking, Willing dan Judging. Ettinger mengungkapkan bahwa Arendt banyak menulis surat kepada Heidegger sepanjang tahun 1971, dan saat mengerjakan The Life of The Mind yang diterbitkan secara anumerta. Arendt menanyai Heidegger soal berpikir, berkehendak dan menilai. Ia juga kembali ke pertanyaan soal kejahatan tahun berikutnya (Ettinger, 2005: 168). Surat-menyurat yang dilakukan Arendt dengan Heidegger menyiratkan bahwa karya-karya Arendt dipengaruhi oleh pemikiran Heidegger, terutama berkaitan dengan konsep berpikir.

Arendt belum menyelesaikan buku Life of The Mind, baru dua jilid yang pertama, Arendt mendadak meninggal karena serangan jantung (Sudiarja, 2007: 68). Hannah Arendt meninggal pada 4 Desember 1975 (Ettinger, 2005: 169). Arendt meninggal dalam usia 69 tahun karena gagal jantung di apartemennya di New York. Arendt dimakamkan di samping suami Arendt di pemakaman Bard College, New York (Owens, 2010: 43). 


\section{FILSAFAT TINDAKAN HANNAH ARENDT}

Filsafat tindakan berasal dari konsep vita activa. Konsep vita activa merumuskan tiga aktivitas manusia, antara lain : kerja, karya dan tindakan. Hannah Arendt (1958: 7) menjelaskan bahwa:

With the term vita activa, I propose to designate three fundamental human activities: labor, work and action. They are fundamental because each corresponds to one of the basic conditions under which life on earth has been given to man. Labor is the activity which corresponds to the biological process of the human body. Work is the activity which corresponds to unnaturalness of human existence, which is not imbedded in, and whose mortality is not compensated by, the species ever-recurring life cycle. Action, the only activity that goes on directly between men without the intermediary of things or matter, corresponds to the human condition plurality, to the fact that men, not Man, live on the earth and inhabit the world.

Istilah vita activa merupakan istilah yang memiliki muatan tradisi, di mana tradisi tersebut sama tuanya dengan tradisi pemikiran politik. Secara historis, istilah vita activa berasal dari pemikiran Aristoteles biospolitikos. Istilah biospolitikos ini digunakan pada filsafat Abad Pertengahan oleh Agustinus dengan istilah vita negotiosa atau actosa dengan makna "a life devoted to public-political matters" (mempersembahkan hidup untuk urusan politik-publik) (Arendt, 1958: 12).

Konsep vita activa terinspirasi dari tiga taraf kehidupan dalam pemikiran Aristoteles. Tiga taraf aktivitas tersebut adalah produksi, tindakan dan kontemplasi. Arendt kemudian mengkritik tiga taraf aktivitas tersebut, bahwa tindakan diletakkan di bawah kontemplasi. Bagi Arendt, tindakan adalah penyempurna aktivitas manusia sehingga tindakan menjadi aspek penting di dalam vita activa.

Vita activa digunakan Arendt bukan untuk dibandingkan dengan vita contemplativa, kedua hal tersebut mempunyai muatan yang sama. Hal ini berarti bahwa baik vita activa maupun vita contemplativa memi- 
liki tingkatan yang seimbang, tidak ada yang lebih tinggi atau lebih rendah. Menurut Arendt (1958: 17) bahwa:

The modern reversal shares with the traditional hierarchy the assumption that the same central human preoccupation must prevail in all activities of men, since without one comprehensive principle no order could be established. This assumption is not a matter of course, and my use ot he term vita activa presupposes that the concern underlying all its activities is not the same as and is neither superior nor inferior to the central concern of the vita contemplativa.

Vita activa memperoleh perhatian Arendt untuk mengkritik kemajuan masyarakat modern yang hanya menekankan "berpikir" untuk hal-hal praktis, seperti revolusi ilmiah. Perkembangan kemajuan masyarakat modern yang menurut Arendt (1958: 257-258) dimulai dari penemuan teleskop oleh Galileo, penemuan benua amerika, eksplorasi terhadap seluruh bumi melalui hukum gravitasi Newton, dan mencapai puncaknya pada penemuan pesawat terbang serta penaklukan ruang angkasa. Arendt (1958: 265) menjelaskan bahwa manusia menyadari kebebasannya dari belenggu pengalaman, dan kemudian mereka menempatkan alam di bawah kondisi pikirannya sendiri, yaitu dari sudut pandang kemenangan universal, astrofisika dan sudut pandang kosmik di luar alam.

Kemenangan universal memungkinkan terjadinya pembalikan hirarki, di mana vita activa lebih tinggi kedudukannya dibandingkan vita contemplativa. Kehidupan aktif lebih diutamakan daripada kehidupan perenungan, yang juga berdampak pada kemenangan animal laborans yang tak pernah lengkap tanpa proses sekularasi (Arendt, 1958: 320). Akibat dari kemenangan animal laborans adalah tidak ada batasan antara ruang publik dan ruang privat. Dampak lain dari ketidakseimbangan vita activa dengan vita contemplativa, seperti yang dipaparkan Hardiman (2003: 25) bahwa:

Manusia percaya begitu saja apa-apa yang terjadi secara rutin dengan perspektif akal sehatnya. Term vita contemplativa 
bahkan menjadi bahan perbincangan di era postmodern. Vita contemplativa identik dengan teori, sementara dalam realitas kehidupan tidak melulu menggunakan teori, bahkan teori harus dikaitkan dengan praksis. Persoalan yang muncul kemudian adalah tidak ada keseimbangan dalam penggunaan teori dan praksis, seperti ketika kita terbiasa menghayati daripada memikirkan atau sebaliknya. Jika lewat dari wilayah ini, manusia merasa ada sesuatu yang "aneh", "luar biasa", "gila", dan seterusnya. Wilayah ini belum direfleksikan, maka bersifat prareflektif, sebuah "wilayah tidak bertuan" yang belum diduduki oleh penafsiranpenafsiran ilmiah dan filosofi. Manusia di sini lebih "menghayati" daripada "berpikir", atau kalaupun berpikir, berpikir untuk hal-hal praktis yang sudah barang tentu.

Kajian tentang vita activa tidak terlepas dari kehidupan mental manusia, artinya bahwa di dalam kehidupan aktif, manusia diharuskan "berpikir". Manusia dengan berpikir akan membedakan manusia dengan makhluk lainnya. Arendt (1958: 284) menjelaskan bahwa:

The old definition of man as an animal rationale acquires a terrible precision: deprived of the sense through which man's five beings are indeed no more than animals who are able to reason, to reckon with consequences.

Manusia dibedakan dari makhluk lain, terutama dengan kemampuan manusia berpikir. Berpikir bukan hanya berpikir seperti hal-hal praktis yang telah diatur dalam sebuah sistem, seperti birokarsi. Berpikir merupakan aktivitas di mana terjadi dialog antara diri dengan suara batin, sehingga berpikir memerlukan aspek kesadaran, bukan hanya dengan menghayati namun dengan bertindak.

Kemampuan manusia berpikir akan diuji dalam tiga aktivitas kehidupan manusia, yaitu: aktivitas kerja, karya dan tindakan. Tujuan pembagian ini adalah merumuskan bahwa dengan adanya refleksi diri, maka manusia berani berpikir terutama dalam menghadapi setiap persoalan. Kemampuan berpikir hanya terjadi di dalam aktivitas ma- 
nusia yang paling ultim, di mana manusia mampu hidup bersama dalam keberbedaan. Aktivitas ultim manusia hanya akan tercapai, jika disertai dengan aktivitas-aktivitas yang lainnya, seperti kerja dan karya. Manusia tidak akan menjadi manusia dengan kemampuan ultim, jika tidak didukung oleh orang-orang yang hidup di ranah aktivitas lebih rendah dari aktivitas tindakan.

Refleksi vita activa menekankan pada ranah kerja, karya dan tindakan. Kerja adalah aktivitas yang berhubungan dengan proses biologis, yang tumbuh dengan spontan, bermetabolisme dan terikat dengan proses produksi. Kehidupan yang menuntut manusia agar memproduksi (Arendt, 1958: 7). Hal ini berarti bahwa proses kehidupan manusia dituntut untuk bekerja dan memproduksi. Tujuan hidup manusia adalah dengan memenuhi kebutuhannya, yaitu dengan bekerja. Arendt (1958: 98-99) menjelaskan bahwa bekerja selalu bergerak di lingkaran yang sama, yang dinyatakan dengan proses kehidupan biologis dan berakhir hanya dengan datangnya kematian. Definisi kerja di sini dimulai dari pemikiran Marx bahwa kerja tergabung dengan subjek, sehingga kerja dan konsumsi dianggap sebagai kebutuhan dasariah manusia.

Manusia yang bekerja hanya menekankan pada kebutuhan biologisnya. Hal ini berarti bahwa hanya ada dua keharusan dalam wilayah kerja yaitu bekerja dan konsumsi. Manusia dalam aktivitas kerja disebut dengan animal laborans (binatang yang bekerja). Manusia dalam aktivitas ini kehilangan identitas dirinya, dan tergantikan oleh kerja dan konsumsi. Manusia tidak mampu beremansipasi, karena emansipasinya hanya demi pemenuhan kebutuhan dan konsumsi, dan hanya mampu dicapai dengan bekerja. Animal laborans belum mampu membentuk sebuah ruang publik, di mana setiap orang mampu memahami dan sadar terhadap realitas kehidupan.

Kerja bersifat sangat privasi sehingga individu belum mampu membentuk ruang publik di dalamnya. Komunitas yang terbentuk hanya sekedar memperoleh kebahagiaan terhadap konsumsi barang. Komunitas yang terbentuk bukan datang dari emansipasi kelas pekerja namun berdasarkan emansipasi aktivitas kerja sendiri (Arendt, 1958: 
126). Itulah mengapa teori Marx mengenai masyarakat kelas pekerja dianggap utopis, karena manusia di dalam ranah kerja hanya memikirkan kebutuhan konsumsi dan bekerja. Jika kebutuhannya telah tercukupi, maka mereka akan berhenti memperjuangkan kesetaraan kelas sehingga revolusi tidak akan tercapai apabila masyarakat hidup di dalam ranah kerja.

Tujuan hidup kelas pekerja adalah untuk bekerja dan konsumsi. Komunitas yang dibangun berdasarkan keseragaman bukan pada kesadaran setiap individu. Manusia pada tingkat kerja belum mampu bersikap kritis, kreatif dan inisiatif. Setiap aktivitas yang tidak berhubungan dengan kerja disebut hobi. Hobi di sini berhubungan dengan kesamaan konsumsi, di mana setiap orang membentuk komunitas berdasarkan pada kesamaan menggunakan produk tertentu.

Aktivitas manusia yang kedua adalah karya. Manusia di dalam ranah karya disebut dengan homo faber. Kata latin faber berasal dari facere, yang dalam arti produksi berarti membuat sesuatu (Arendt, 1958: 136). Karya diawali dengan adanya penemuan alat-alat produksi, yang membantu manusia dalam meningkatkan produktivitas kerja. Peningkatan produksi secara besar-besaran adalah salah satu alasan mengembangkan pembagian kerja, yaitu dengan mengurangi tenaga kerja dan menggantinya dengan alat-alat produksi. Hal ini terinspirasi dari konsep nilai dari Adam Smith. Teori nilai kerja Smith memungkinkan seseorang cenderung menukarkan produk mereka sesuai dengan waktu rata-rata untuk menghasilkannya, sehingga seseorang cenderung menggunakan alat-alat produksi daripada menyewa tenaga kerja. Manusia dengan menggunakan alat-alat produksi, maka akan memberikan keuntungan bagi pemilik modal. Jika dibandingkan dengan menyewa tenaga kerja, keuntungan yang didapat tidak lebih besar daripada menggunakan alat-alat produksi. Dampak positif dari penggunaan teori ini adalah meningkatkan efisiensi kerja dan mengurangi biaya produksi, karena telah ditemukan alat-alat produksi yang lebih murah. Kelemahan teori ini berakibat pada jumlah pengangguran yang terus bertambah, sehingga menimbulkan persoalan sosialekonomi di dalam masyarakat. 
Arendt (1958: 136) menjelaskan bahwa kerja yang mengandalkan tenaga dibedakan dengan karya yang mengandalkan kreativitas membuat. Menurut Arendt bahwa terdapat "nilai" yang Adam Smith butuhkan untuk pasar jual-beli, dan mereka menanggung kesaksian pada produktivitas, yang dipercayai Marx menjadi ujian bagi sifat manusia. Jika dibandingkan dengan aktivitas sebelumnya, karya memang berbeda dengan kerja. Manusia seringkali menjadi budak dari pekerjaannya jika di dalam ranah kerja, namun di dalam karya, sudah terdapat kreativitas pada manusia, yang justru menjadi ujian bagi kehidupan manusia. Ujian atas kreativitas manusia adalah manusia sudah mampu menghasilkan produk yang lebih besar, dengan membuat alat-alat produksi, seperti mesin tenun. Mesin tenun dianggap sederhana dan murah, namun pemanfaatan mesin menimbulkan dampak bagi alam sekitar. Bagi Arendt (1958: 139) bahwa akan terjadi kerusakan alam dengan penemuan alat-alat produksi. Jika animal laborans masih menjadi pelayan bagi alam dan bumi, bagi home faber, sikapnya sendiri seolah-olah menjadi penguasa bagi seluruh bumi.

Kelemahan lain dari kemenangan homo faber adalah jika hubungan antara manusia dan dunianya tidak lagi aman, sehingga kebahagiaan dimaknai sebagai sebuah pengalaman menderita atau menyenangkan, dalam memproduksi atau mengkonsumsi sesuatu (Arendt, 1958: 309). Bagi masyarakat zaman modern, di mana mereka berada di dalam ranah karya, bahwa suatu tindakan hanya dibenarkan sejauh dapat menghindarkan penderitaan. Hal ini seperti dalam penemuan Bentham tentang "perhitungan tentang penderitaan dan kenikmatan."

Menurut Arendt bahwa asumsi dasar Bentham diperoleh dari filsafat awal abad modern, yaitu filsafat Hedonisme. Prinsip hedonisme adalah prinsip bukan kenikmatan, namun menghindari penderitaan. Hume sebagai lawan Bentham, mengetahui dengan sangat baik bahwa untuk menciptakan kenikmatan sebagai tujuan akhir tindakan manusia adalah sebuah perjalanan dengan mengenal bukan kenikmatan, namun penderitaan, bukan hasrat namun ketakutan yang merupakan petunjuk sebenarnya (Arendt, 1958:309).

Manusia dalam ranah karya, percaya bahwa sesuatu tersebut benar sejauh dapat diserap dengan mata dan pikiran. Homo faber, 
meskipun setingkat lebih maju dari animal laborans, kebebasan masih terkungkung oleh aktivitas hasil produksi sehingga belum memungkinkan terbentuk identitas diri yang mampu memberikan perubahan di dalam realitas kehidupan. Identitas diri juga tidak dapat dibangun berdasarkan keinginan menguasai alam dan manusia di sekitarnya, sehingga identitas diri hanya dapat dibangun di dalam aktivitas tindakan.

Aktivitas manusia yang paling ultim adalah tindakan. Tindakan menjadi aktivitas paling ultim karena di dalam tindakan, manusia sudah mengenal kebebasan dan memahami pluralitas. Menurut Arendt (1958: 175) bahwa di dalam ranah tindakan terdapat dua karakter masyarakat pluralitas yaitu: pertama, jika manusia tidak sama, maka mereka tidak akan saling memahami. Kedua, jika manusia tidak mempunyai perbedaan, maka masing-masing orang tidak dapat dibedakan dari yang lain.

Dua karakter dalam masyarakat pluralis tersebut, mengandaikan adanya dua hal yang saling berlawan. Masyarakat pluralis memiliki kelebihan dalam keunikannya, namun sekaligus terdapat konsekuensi yang mesti ditanggung apabila mereka tidak mampu memahami keunikan tersebut. Arendt menawarkan kemampuan berbicara untuk memahami keberbedaan di dalam ranah tindakan.

Kemampuan manusia berbicara memainkan peranan penting dalam ranah tindakan, karena tanpa wicara maka tindakan akan kehilangan subjek. Sebaliknya tanpa tindakan, manusia hanya akan seperti robot. Arendt menekankan bahwa dengan bertindak dan berbicara, manusia menunjukkan siapa mereka, mengungkapkan identitas personal mereka dan menampilkan penampilan dalam bentuk dan suara yang unik (Arendt, 1958: 179). Keunikan dalam masyarakat pluralitas bisa menjadi alat untuk mempersatukan dan memahami perbedaan, maka untuk menjalin sebuah pemahaman, diperlukan wicara sebagai bentuk komunikasi dan ekspresi diri secara bebas. Kebebasan wicara dalam tindakan membutuhkan adanya kesadaran seseorang bahwa di dalam realitas kehidupan dipenuhi oleh keberbedaan. Setiap orang di dalam ranah tindakan, mampu memahami bahwa tidak semua orang 
memiliki gagasan yang sama. Keberbedaan di sini dipahami untuk menghindari dari kesalahpahaman dalam bertindak, sehingga berpikir dari sudut pandang orang lain menjadi tindakan penting di dalam kebersamaan.

Kebersamaan merupakan pengakuan adanya pluralitas. Pluralitas terjadi adanya hubungan antara manusia yang disertai kreativitas dan insiatif diri. Menurut Arendt (1958: 7) bahwa keberadaan pluralitas ini, yakni ada banyak perspektif dan suara-suara yang membentuk jagat politik, adalah fakta objektif. Ketika kesetaraan jamak datang bersama untuk memperdebatkan urusan bersama mereka, maka kita dapat mengatakan bahwa wilayah publik telah dibuat. Melalui wicara dan tindakan di dalam pluralitas, orang membentuk space in between (ruang antara) mereka bisa ada tanpa hal atau materi yang jadi perantara. Ruang antara berarti bahwa untuk hidup di antara sesama, kita tidak menggunakan alasan-alasan baik material maupun praktis namun memerlukan kerelaan dan kemurahan hati. Ruang publik dapat dijalin berdasarkan kesadaran akan kehidupan di antara sesama manusia.

Menurut Arendt (1958: 220) bahwa ada tiga tindakan frustasi dalam zaman modern, yaitu ada suatu proses yang tidak bisa dikembalikan ke titik nol; adanya hasil yang tidak dapat diprediksi; serta adanya pengarang yang tidak diketahui identitasnya. Tiga kelemahan tindakan manusia dapat dijawab berdasarkan beberapa karakter aktivitas tindakan.

Persoalan pertama adalah sebuah tindakan atau wicara yang tidak dapat dikembalikan ke titik nol. Persoalan ini berarti bahwa apa yang telah kita lakukan atau ucapkan, tidak dapat dikembalikan, seolah-olah kita tidak pernah melakukan atau mengucapkannya. Arendt untuk mengatasi persoalan ini, menawarkan konsep ampunan terhadap kesalahan yang telah diperbuat. Seseorang dengan mengampuni, maka mampu membuka lembaran baru dalam menghadapi kehidupan. Ampunan juga dapat mengatasi dendam-dendam masa lalu, karena dengan mengampuni maka seseorang memberikan kesempatan baru bagi orang lain untuk instropeksi dan memulai kehidupan baru.

Mengampuni merupakan tindakan yang dilakukan untuk melawan kesalahan atau dosa. Mengampuni adalah tindakan di mana salah 
satu orang memberikan ampunan, sementara yang lainnya menerima ampunan. Ajaran Jesus tentang mengampuni, sebenarnya adalah konsep pembebasan dari balas dendam. Hal ini berarti bahwa mengampuni adalah tindakan memutus siklus dendam antara pelaku dengan korban.

Tindakan mengampuni hanya dapat dilakukan berdasarkan cinta. Arendt (1958: 242) menjelaskan bahwa hanya cinta yang mampu mengampuni karena hanya cinta yang benar-benar menerima kesalahan seseorang. Arendt menawarkan bukan hanya cinta, namun juga rasa hormat. Rasa hormat berarti bahwa adanya persahabatan antara dua orang atau lebih, tanpa hubungan seksual. Rasa hormat di sini menekankan pada hubungan persahabatan, yang tidak hanya didasari oleh cinta, namunjuga rasa pertemanan.

Persoalan kedua adalah adanya tindakan yang tidak mampu diprediksi. Hal ini berarti bahwa baik tindakan ataupun wicara yang diungkapkan ke dalam dunia penampakan selalu berkembang dan menyatu dengan masyarakat yang plural. Akibat dari hal tersebut adalah terjadi beragam interpretasi yang tidak mampu kita kendalikan, sehingga memungkinkan kita untuk membuat sebuah janji untuk memberikan jaminan terhadap tindakan atau ucapan yang tidak dapat kita prediksi.

Kemampuan manusia memaafkan dan memberikan janji merupakan bukti bahwa kehidupan harus terus berlanjut. Ampunan merupakan jawaban atas tindakan yang tidak dapat diulangi, sementara janji merupakan solusi bagi tindakan yang tidak dapat diprediksi. Manusia akan memiliki jaminan untuk membangun kehidupannya di antara komunitas yang plural dengan ampunan dan janji. Persahabatan di dalam sebuah komunitas sangat diperlukan dengan dasar kerelaan menerima dan memahami perbedaan, karena manusia adalah makhluk yang hidup dan mati di antara yang lain. Arendt (1958: 237) menjelaskan bahwa:

Withou tbeing forgiven, released from the consequences of what we have done, our capacity to act would, as it were, be confines to one single deed from which we could never recover; we would remain 
the victims of its consequences forever, not unlike the sorcerer's apprentice who lacked the magic formula to break the spell. Without being bound to fulfillment of promises, we would never be able to keep our identities; we would be condemned to wander helplessly and without direction in the darkness of each man's lonely heart, caught in its contradictions and equivocalities-a darkness which only the light shed over the public realm through the presence of others, who confirm the identity between the one who promises and the one who fulfils, can dispel. Both faculties, therefore, depend on plurality, on the presence and acting others, for no one can forgive himself; forgiving and promising enacted in solitude or isolation remain without reality and can signify no more than a role played before one's self.

Persoalan ketiga adalah pengarang yang tidak diketahui identitasnya. Pengetahuan terhadap subjek atau pengarang karena pentingnya wicara dalam sebuah komunitas. Untuk menampilkan identitas dirinya, manusia perlu mengekpresikan ke luar dunia penampakan melalui wicara. Komunikasi akan terjalin dengan wicara, sehingga seseorang mampu memahami tindakan orang lain sekaligus menyelesaikan persoalan bersama.

Keunikan filsafat Arendt adalah solusinya terhadap kelemahan tindakan manusia. Penulis menyimpulkan bahwa jawaban atas kelemahan tindakan manusia meliputi, kemampuan manusia mengampuni, kemampuan berjanji dan perlunya wicara untuk menyingkap identitas diri. Filsafat Arendt meskipun mendapatkan ide tentang konsep manusia dari Heidegger dan Jaspers, namun Arendt mampu menempatkan filsafat tindakan sebagai jawaban terhadap persoalan kemanusiaan. Manusia dengan menempatkan dirinya di dalam ranah tindakan, maka akan dengan mudah mengenali martabat atau jatidirinya.

\section{JATIDIRI MANUSIA DALAM FILSAFAT TINDAKAN ARENDT}

\section{Badan dan Jiwa; Jiwa dan Pikiran}

Jatidiri manusia memiliki beberapa aspek, antara lain: aspek uni- 
tas kompleksitas, aspek historisitas dan aspek identitas diri. Aspek unitas mengandaikan adanya kesatuan utuh yang mempunyai kesatuan ganda. Jatidiri mengandaikan adanya kesatuan yang utuh di dalam diri manusia. Kesatuan ini begitu mutlak sehingga terasa begitu jelas ketunggalan di dalam dirinya sendiri yang tidak bisa dibagi-bagi (Hadi, 1996: 25). Aspek unitas-kompleksitas di dalam filsafat tindakan Arendt terdapat pada pemahaman bahwa manusia terdiri dari jiwa dan pikiran. Hubungan jiwa dan pikiran dijelaskan Arendt (1971: 1/123) bahwa:

Without the breath of the life the human body is corpse. Without thinking the human mind is dead.

Kalimat di atas mengandaikan hubungan antara jiwa dan pikiran. Jiwa dan pikiran membentuk sebuah kesatuan utuh, yang terdiri dari bagian-bagian dan aspek-aspek. Jiwa mendukung pikiran dalam membentuk kepribadian manusia. Manusia di dalam berpikir senantiasa memerlukan kehendak dan pertimbangan, di dalam kesatuan kemampuan mental manusia. Berpikir memang bukan suatu hal yang bertujuan ultim, namun dengan berpikir manusia mampu berdialog dengan diri dan suara batin. Arendt (1971: 1/1) menjelaskan berpikir sebagai berikut:

Thinking does not bring knowledge as do the sciences. Thinking does not produce usable practical wisdom. Thinking does not solve the riddles of the universe. Thinking does not endow us directly with the power to act.

Tujuan berpikir bukan untuk mendapatkan pengetahuan, kebijaksanaan, jawaban dari teka-teki alam semesta, atau mendapatkan kekuasaan. Berpikir adalah aktivitas mental yang melibatkan dialog antara diri dengan suara batin, di mana keduanya saling bertentangan satu sama lain. Tujuan berpikir adalah menemukan keseimbangan dan kedamaian di dalam diri manusia. Ketika manusia telah menemukan kedamaian di dalam dirinya, manusia juga harus berhadapan dengan kehendak yang dimiliki. Kehendak adalah proyeksi terhadap masa depan. Arendt (1971: 11/4) menjelaskan bahwa: 
Althought it is always the same mind that thinks and wills, as it is the same self that unites body, soul, and mind, it is by no means a matter of course that the thinking ego's evaluation can be truste to remain unbiased and "objective" when it comes to other mental activites. For the truth of the matter is that the notion of free will serves not only as a necessary postulate of every ethics and every system of laws but it no less an "immediate datum of consciousness" (in the word of Bergson) than the I think in Kant or cogito in Descartes, whose existence was hardly ever doubted by traditional philosophy.

Kehendak cenderung menekankan pada kebebasan, karena kehendak merupakan harapan setiap manusia terhadap masa depan. Arendt (1971: 11/5) menjelaskan bahwa:

Willing, it appears, has an infinitely greater freedom than thinking, which even in its freest, most speculative from cannot escape the law of noncontradiction. This undeniable fact has never been felt to be an unmixed blessing. By men of thought, more often than not, it has been felt to be a curse.

Manusia dalam menemukan keseimbangan antara berpikir dan kehendak, memerlukan pertimbangan. Pertimbangan merupakan kemampuan mental manusia untuk menilai masa lalu, terutama ketika individu hidup di bawah kekuasaan otoriter. Pertimbangan, pada dasarnya merupakan kemampuan manusia dalam menilai berdasarkan pada sudut pandang orang lain dan lingkungan sekitar. Pertimbangan akan diterapkan berbeda ketika kehidupan seseorang di bawah kekuasaan otoriter. Pertimbangan mempersoalkan dua hal. Pertama, bagaimana tanggung jawab personal di bawah sistem kekuasaan otoriter. Kedua, bagaimana independensi manusia jika tidak didukung oleh hukum dan opini publik.

Analisis Arendt dalam menjawab persoalan tersebut adalah dengan menekankan pada kemampuan berimajinasi. Hal ini berarti bahwa dengan imaginasi, manusia mampu memposisikan dirinya dari sudut pandang orang lain. Arendt menjelaskan dalam Beiner (1982: 97) 
bahwa tanpa imajinasi, kita tidak akan mampu mengambil semua tanggungan kita di dunia. Iamjinasi hanya pedoman batin yang kita miliki. Kemampuan manusia selain imajinasi adalah kemampuan mengampuni. Arendt menjelaskan bahwa pengampunan mengikuti pertimbangan. Pengampunan tidak dapat disamakan dengan keadilan, namun kemurahan hati (Arendt, 1971: 296). Kemampuan mental manusia diharapkan mampu mengatasi kejahatan banal, yaitu kejahatan yang dilakukan dengan enteng dan dangkal. Pemahaman berdasarkan aspek-aspek kemampuan mental (berpikir, kehendak, pertimbangan) yang matang, mampu membentuk jatidiri manusia sebagai satu kesatuan yang utuh. Setiap manusia akan mampu memahami dirinya sendiri dalam satu kesatuan yang utuh. Tindakan yang dilakukan setiap pribadi adalah tindakan disertai dengan kesadaran tinggi dan bertanggung jawab.

\section{Historisitas Manusia}

Manusia berkembang dari masa lalu, masa sekarang dan masa depan. Masa lalu dan masa sekarang ditempuh untuk membentuk masa depan. Arendt menjelaskan bahwa penekanan pada becoming, yaitu bukan being tapi becoming terinspirasi dari Hegel. Hal ini berarti bahwa masa depan lebih penting melebihi masa sekarang dan masa lalu (Arendt, 1971: 11/47). Manusia dilihat perkembangan kehidupan yang selalu berproses, sehingga manusia adalah pribadi yang selalu terlahir kembali. Keterlahiran membuka kemungkinan untuk melakukan pembaharuan. Pembaharuan mampu memberikan kesempatan baru bagi tindakan manusia.

Pembaharuan pada masa sekarang, harus disertai dengan kesadaran berpikir. Kesadaran berpikir digunakan dalam situasi yang plural. Menurut Arendt yang dikutip Brunkhost (2006: 188) bahwa:

Everything we do happens relative to this situation. Being there, in this particular historical situation, we make our own plans, which in turn intersect a world made up of a plurality of other people's projects and possibilities, yet ultimately, what we do and what we are depends on ourselves, despite the situational aspect of our lives. 
Kesadaran berpikir penting digunakan dalam kehidupan manusia. Situasi kehidupan manusia yang cenderung berubah-ubah, diperlukan kesadaran berpikir dalam setiap tindakan yang dilakukan manusia. Kesadaran berpikir mampu menghindari tindak kejahatan karena kelemahan manusia dalam bertindak. Kelemahan tindakan manusia antara lain antara lain: pertama, adanya tindakan yang tidak dapat dikembalikan ke titik nol, dan selalu menorehkan ingatan sosial.

Kedua, tindakan yang tidak dapat diprediksi hasilnya. Arendt menjelaskan bahwa dengan memberikan ampunan dan janji, maka manusia mampu mengatasi kelemahan tindakan tersebut. Menurut Arendt (1958: 237) bahwa:

Without being forgiven, released from the consequences of what we have done, our capacity to act would, as it were, be confined to one single deed from which we could never recover; we would remain the victims of its consequences forever, not unlike the sorcere's apprentice who lacked the magic formula to break the spell. Without being bound to the fulfilment to promise, we would never be able to keep our identities; we would be condomned to wander helplessly and without direction in the darkness of each man's lonely heart, caught in its contradictions and equivocalities a darkness which only the one who fulfils, can dispel.

Kemampuan manusia mengampuni akan memutus dendam yang terus terulang, dan membuka kemungkinan baru bagi setiap manusia. Janji akan memberikan kepastian dalam menghadapi masa depan yang tidak dapat diprediksi.

\section{Nilai-nilai Sosialitas Manusia}

Manusia adalah makhluk sosial. Sosialitas manusia tidak terlepas dari kehidupan manusia dengan orang lain. Manusia di dalam kehidupan, diciptakan berbeda-beda. Keberbedaan menuntut rasa saling menghargai dan menghormati antara sesama manusia, dan tercipta persahabatan. Arendt (1971: II/98) menjelaskan bahwa:

The paradigm for a mutually predicated relatinship of independent "substances" is friendship: two men who are friends can be said to 
be "independent substances" insofar as they are related to themselves; they are friends only relatively to each other. A pair of friends froms a unity, a one, insofar and as long as they are friends; the moment the friendship ceases they are again two "substances," independent of each other.

Persahabatan merupakan dua substansi, namun masing-masing memiliki independensi. Mereka saling terikat dan membentuk satu kesatuan dalam persahabatan. Tujuan persahabatan adalah hidup dan mati di antara. Manusia memahami bahwa kehidupan adalah spesial dan unik dalam keberbedaan. Keunikan bukan dengan menonjolkan individualitas, namun dengan kebersamaan. Kebersamaan membentuk setiap individu sebagai penyempurna kehidupan.

Jatidiri manusia di dalam filsafat tindakan Arendt, dapat disimpulkan sebagai berikut: pertama, manusia terdiri dari aspek unitaskompleksitas. Manusia terdiri dari aspek-aspek yang utuh, masingmasing aspek salaing terkait, sehingga tidak dapat hanya dengan mengandalkan pikiran tanpa jiwa atau sebaliknya. Kedua, identitas manusia mengandaikan bahwa manusia berkembang dan berproses dalam kehidupan. Manusia selalu berkembang menjadi, artinya bahwa identitas diri dapat diketahui di akhir kehidupan manusia. Ketiga, keunikan manusia yang tercermin dari kemampuannya membangun persahabatan di dalam kehidupan yang plural. Keberbedaan bukan halangan untuk membangun komunitas, dengan berbeda maka akan terbentuk sebuah komunitas yang di dalamnya terdapat beragam keunikan diri. Kesimpulan tersebut mengandaikan bahwa jatidiri manusia dalam filsafat tindakan Arendt adalah adanya kepribadian yang utuh, yang terdiri dari pikiran dan jiwa; identitas diri yang selalu mengalami perubahan; dan adanya sikap menghargai dan menghormati dengan membangun persahabatan. Pemahaman berdasarkan jatidiri manusia di dalam filsafat tindakan, mampu memberikan jawaban alternatif dalam kasus Genosida dalam Kamp Konsentrasi.

Pemahaman jatidiri manusia berdasarkan filsafat tindakan Arendt, juga akan diterapkan pada persoalan pelanggaran HAM tahun 1965-1966 yang terjadi di Indonesia. Kasus Eichmann memiliki 
persamaan dengan kasus pelanggaran HAM 1965-1966, terutama keduanya berada di bawah kekuasaan otoriter. Penulis berharap dapat menganalisis kasus di Indonesia dengan menggunakan jatidiri manusia di dalam filsafat tindakan Arendt. Penulis bertujuan menemukan pandangan yang berbeda, sehingga dapat digunakan sebagai pemahaman dalam menghormati hak asasi setiap manusia.

\section{RELEVANSI JATIDIRI MANUSIA}

\section{DALAM FILSAFAT TINDAKAN ARENDT TERHADAP PELANGGARAN HAM TAHUN 1965-1966 DI INDONESIA}

Hannah Arendt mengandaikan kasus Eichmann sebagai analisis filsafat tindakan Arendt. Kasus Eichmann menunjukkan bahwa kejahatan dapat dilakukan dengan dangkal. Kejahatan seperti Genosida dilakukan bukan karena alasan tertentu, namun karena ketidakmampuan Eichmann berpikir dan memahami situasi di bawah kekuasaan otoriter. Hal ini berarti bahwa tindak kejahatan bukan terjadi karena kesalahan sistem atau lingkungan sekitar, namun karena ketidakmampuan seseorang berpikir, berimajinasi terhadap tindakannya. Hal tersebut juga dialami bangsa Indonesia sekitar tahun 1965-1966. Pelaku kejahatan maupun pelaku pembalas-dendam melakukan tindak pelanggaran HAM, yaitu menuduh, menganiaya dan membunuh tanpa proses peradilan. Tindak pelanggaran HAM tersebut dilakukan dengan enteng, karena terdapat doktrin dari penguasa yang otoriter. Doktrin bisa berupa doktrin paham komunis yang bertentangan dengan Pancasila, maupun doktrin jaman Orde Baru yang mengharamkan segala bentuk paham dan aliran komunis. Persoalan tindak kejahatan yang melanggar HAM dapat diselesaikan dengan pemahaman berdasarkan jatidiri manusia dalam filsafat tindakan. Kemampuan manusia mengenali jatidirinya, terutama jika kita belajar dari analisis Arendt terhadap kasus Eichmann, diharapkan mampu menanggulangi kejahatan banal di masa depan.

Arendt menulis The Life of The Mind dalam menjawab persoalan kejahatan banal Eichmann. Tindakan Eichmann bukan dianggap bodoh, tapi thoughtlessness. Hal ini berati bahwa ketidakmampuan Eich- 
mann berpikir dari sudut pandang orang lain. Ketidakmampuan ini mendorong Arendt menjelaskan aktivitas mental manusia, yaitu berpikir, kehendak dan pertimbangan. Aktivitas mental tersebut diharapkan mampu mempertimbangkan tindakan yang akan kita lakukan. Hal ini juga berlaku dalam analisis penulis tentang pelanggaran HAM tahun 1965-1966 di Indonesia. Para pelaku maupun pembalas dendam melakukan tindak kejahatan pembunuhan dengan enteng atau dangkal.

Persoalan setelah peristiwa pelanggaran HAM masa lalu adalah adanya ingatan sosial yang tidak bisa dihapus. Ingatan sosial bertujuan untuk membangun sejarah bangsa yang benar. Hal ini berarti bahwa bangsa tanpa sejarah akan menjadi bangsa yang tidak utuh. Realitas di dalam kehidupan saat ini adalah belum ada proses peradilan yang digelar, baik untuk mengadili pelaku kejahatan maupun memulihkan ingatan sosial masyarakat. Jika kita belajar dari peristiwa Genosida, kaum Yahudi telah menggelar pengadilan Nuremberg sebagai bentuk pemulihan ingatan sosial. Pelanggaran HAM di Indonesia belum mampu menggelar pengadilan, dan mengakui bahwa di Indonesia telah terjadi pelanggaran HAM berat tahun 1965-1966. Solusi lain dari proses peradilan adalah dengan pemahaman berdasarkan jatidiri manusia dalam filsafat tindakan Arendt.

Penulis akan memaparkan beberapa langkah-langkah dalam membangun pemahaman tersebut, antara lain:

\section{Membangun Kesadaran Berpikir}

Kejahatan yang banal merupakan akibat dari kepatuhan seseorang terhadap sistem. Kepatuhan seorang pegawai rendahan terhadap atasannya memang dianggap sebagai bentuk loyalitasnya. Seorang pribadi dengan kemiskinan imajinasi dan empati akan serta-merta menjalankan perintah tanpa kesadaran berpikir. Arendt menjelaskan dalam D'entreves (2006: 248) bahwa:

Arendt wrote that awakened my interest. Is evil-doing (the sins of omission, as well as the sins of commission) possible in default of not just "base motives". But of any motives whateever, of any particular prompting of interest or volition? 
Is wickedness. Not a necessary condition for evil doing? Might the problem of good and evil, our faculty for telling right from wrong, be connected with our faculty of thought.

Seseorang perlu membangun kesadaran berpikir. Berpikir akan memberikan waktu berdialog bagi diri dan suara batin. Manusia akan menemukan ketenangan dengan berpikir. Hal ini berarti bahwa seorang pribadi perlu memahami suara batinnya, terutama di bawah situasi yang tidak dapat diprediksi. Berpikir akan menumbuhkan penilaian terhadap berbagai situasi, sekaligus menumbuhkan kesadaran terhadap apa yang kita katakan, kita lakukan dan akibat dari tindakan kita.

Kesadaran berpikir akan menghindari dari tindak kejahatan banal. Kejahatan yang dilakukan dengan dangkal, seperti yang terjadi pada pembunuhan antara tahun 1965-1966. Pembunuhan baik yang dilakukan penganut komunis maupun dari pihak militer, diduga akibat dari kurangnya kesadaran berpikir, terutama dalam memahami dirinya dengan suara batin. Ketidakmampuan berpikir sekaligus menghilangkan kemampuan mempertimbangkan. Tindakan yang dilakukan cenderung membabi-buta, tidak mampu berpikir dari sudut pandang korban, dan dilakukan dengan enteng atau dangkal. Manusia dalam situasi seperti ini, akan melakukan perintah dari atasan layaknya robot yang dijalankan tanpa dapat menggunakan kemampuan mental dengan baik.

2. Manusia dipahami dalam keterlahiran

Setiap manusia berkembang dan berproses membentuk jatidiri yang utuh. Jatidiri manusia hanya dapat dinilai ketika proses kehidupan berakhir. Masa lalu dan masa sekarang digunakan untuk membentuk proyeksi di masa depan, sehingga manusia dilihat mengalami kebaharuan dalam kehidupan. Kebaharuan diandaikan dengan keterlahiran. Arendt menjelaskan bahwa:

Dari sudut filsafat, bertindak adalah jawaban manusia terhadap kondisi natalitas (keterlahiran). Karena kita semua memasuki sebuah dunia melalui keterlahiran, kita 
bahkan tidak tahu apa sesungguhnya kebaharuan itu. Semua tindakan akan menjadi perilaku atau pelestarian semata. Tidak ada kemampuan lain kecuali bahasa, baik rasio maupun kesadaran, yang tidak membedakan kita secara begitu radikal dari semua spesies binatang lain. bertindak dan memulai tidaklah sama, tetapi keduanya saling berkait secara erat (Arendt, 1970: 82).

Manusia dengan keterlahiran akan membuka kemungkinankemungkinan baru bagi kehidupan. Kemungkinan yang baru mengandaikan situasi di mana kesalahan pada masa lalu dapat dihapus, yaitu dengan kemampuan manusia mengampuni. Hal ini bisa kita terapkan pada peristiwa pelanggaran HAM di masa lalu, di mana sejarah telah menorehkan cerita kelam tentang pembunuhan dan penganiayaan. Ampun atau maaf membantu mengembalikan kepada titik nol atau rekonsiliasi. Memohon ampun atau mengampuni bukan tindakan logis. Logis, bila orang disakiti membalas menyakiti. Logis, bila orang dirugikan menuntut mendapatkan ganti rugi. Mohon ampun atau mengampuni melampaui logika kesalingan, ia berasal dari kemurahan hati (Haryatmoko, 2003: 89). Jika berangkat dari logika, memang logis bila pembunuhan para pemuka agama dan pembunuhan petinggi Angkatan Darat dibalas dengan pembantaian besar-besaran pengikut, simpatisan bahkan keluarga yang dianggap PKI. Kemampuan mengampuni melampaui logika kesalingan. Mengampuni akan menghindari hukuman penjara seumur hidup di Pulau Buru, bahkan hukuman mati terhadap pengikut PKI tanpa proses pengadilan. Ampunan juga akan membuka kemungkinan baru bagi keluarga, yang anggotanya terlibat PKI, dapat diterima di dalam masyarakat. Untuk memahami pentingnya ampunan dapat kita lihat dari pernyataan seorang tokoh agama di Afrika Selatan, yang berjuang membentuk gerakan rekonsiliasi dan amnesti, memaparkan bahwa:

Dalam memaafkan, orang-orang tidak akan diminta untuk melupakan. Sebaliknya, penting untuk mengingat, sehingga kita sebaiknya tidak membiarkan kekejaman 
semacam ini terjadi lagi. Pengampunan tidak berarti, tidak menyesalkan apa yang telah diperbuat. Ini berarti menganggap serius apa yang telah terjadi dan tidak menguranginya; dengan menarik kemarahan pada memori yang mengancam akan meracuni keseluruhan eksistensi kita. Ini melibatkan usaha untuk memahami para penjahat dan juga memiliki empati, untuk mencoba berdiri di pihak mereka, dan mengekspresikan berbagai tekanan dan pengaruh yang mungkin telah mengantarkan mereka mengerjakan perbuatan mereka tersebut (Desmon Tutu, 2007:314).

Kekuatan mengampuni adalah suatu tindakan menumbuhkan toleransi, dan memahami keberbedaan. Arendt meyakinkan bahwa hanya cinta mampu memaafkan, karena hanya cinta yang benar-benar menerima seseorang, apa pun yang dia lakukan. Mengampuni ditujukan kepada korban, dalam kerangka berdamai dengan ingatan sosial. Untuk memberikan ampunan, juga diperlukan janji agar dapat memutus siklus dendam. Janji berkaitan dengan kesetiaan terhadap tanggung jawab sebagai identitas diri manusia.

3. Membangun persahabatan dalam komunitas

Komunitas dalam pengertian Arendt adalah wadah yang menjamin hak asasi setiap anggotanya. Komunitas di dalam masa sekarang, dapat dipahami dengan konsep negara. Negara memiliki undang-undang yang menjamin kebebasan serta hak asasi setiap warga negara. Manusia yang tidak berkewarganegaran (stateless) di dalam pengertian Arendt, dianggap tidak dapat dijamin kepemilikan hak asasi. Seseorang yang stateless dan pencari suaka cenderung menjadi korban tindak kejahatan. Arendt memberikan pengandaian tentang hancurnya tembok kota, yang kemudian terjadi naturalisasi. Hardiman menjelaskan (2011: 191) bahwa akibat dari naturalisasi adalah masyarakat mengalami krisis solidaritas, individu-individu yang tercerabut dari komunitas itu menjadi atom-atom yang apatis terhadap politik, dan akhirnya hukum survival hidup atau mati 
menjadi aturan harian yang menyingkirkan saling pengertian, empati dan respek akan perbedaan.

Hal ini berarti bahwa individu-individu perlu untuk membangun komunitas, di mana di dalam komunitas, terjalin persahabatan yang mampu menjaga mereka dari hukum survival. Persahabatan yang dijalin bukan berdasarkan persamaan, namun pada perbedaan dan ketidaksamaan. Arendt mengacu pada pendapat Aristoteles dan Sokrates dalam menjelaskan persahabatan, bahwa:

As Aristoteles says, a community is not made out of equals, but on the contrary of people who are different and unequal, and who therefore rely on the exchange of oponion in friendship to equalize themselves. Sokrates too, on Arendt's account that seems to have believed that the political function of the philosopher was to help establish this kind of common world, built on the understanding of friendship, in which no rulership is needed (Dolan, 2006: 267).

Kemampuan manusia menjalin persahabatan memungkinkan individu hidup dalam situasi yang aman. Hal ini dapat diterapkan dalam kasus pelanggaran HAM di Indonesia. Para korban yang tetap diakui kewarganegaraannya oleh pemerintah Indonesia, dapat menikmati hak asasi manusia yang dijamin negara. Negara yang menjamin hak asasi setiap orang, tanpa ada perbedaan, sekaligus menjamin mereka dari tindak kejahatan. Pengakuan Negara terhadap kewarganegaraan setiap bangsa Indonesia, tidak terlepas dari pengamalan Undang-Undang 1945 yang menjamin kebebasan masing-masing individu. Jika Negara mengabaikan peraturan perundang-undangan, maka negara telah melanggar hukum internasional. Pemerintahan Indonesia saat ini, diharapkan mampu menuntaskan kasus pelanggaran HAM masa lalu. Jawaban dari persoalan pelanggaran HAM pada masa lalu, tidak melulu menggunakan pemahaman berdasarkan jatidiri manusia. Jawaban atas persoalan tersebut, juga harus dibarengi dengan keinginan negara dalam menegakkan peraturan perundang-undangan.

Penulis dalam menganalisis peristiwa pelanggaran HAM 
tahun 1965-1966, dengan pemahaman berdasarkan jatidiri manusia di dalam filsafat tindakan Arendt, dapat disimpulkan sebagai berikut: pertama, manusia dengan mengunakan kemampuan mental secara optimal, maka akan mampu menghindari dari tindak kejahatan banal. Kedua, pelanggaran HAM pada masa lalu yang tidak mungkin dikembalikan ke titik nol, tidak dapat dihapus dari ingatan sosial masyarakat Indonesia. Setiap warga negara Indonesia, perlu membangun pemahaman bahwa manusia selalu dilahirkan kembali. Pemahaman tentang keterlahiran akan membuka kemungkinan baru dan menghapus dendam yang berkepanjangan. Ingatan sosial tentang adanya pelanggaran HAM, bukan untuk dihapus, namun untuk menjadi pelajaran bahwa setiap manusia mampu memberikan ampunan dan janji untuk menghadapi situasi dalam persahabatan. Ketiga, manusia perlu untuk membangun persahabatan di dalam sebuah komunitas. Persahabatan diperlukan untuk menghindari dari situasi yang tidak dapat diprediksi dan pemberlakuan hukum survival.

\section{SIMPULAN}

Jatidiri manusia dalam filsafat tindakan Arendt memuat tiga aspek, antara lain: pertama, aspek unitas-kompleksitas. Aspek tersebut memuat jiwa dan pikiran sebagai satu kesatuan yang membentuk pribadi manusia. Badan tanpa jiwa, hanya akan seperti mayat. Manusia tanpa berpikir, akan melumpuhkan otak manusia.

Berpikir merupakan salah satu kemampuan mental manusia. Manusia dengan berpikir dapat memahami jatidirinya. Aktivitas berpikir, selalu disertai dengan kehendak dan pertimbangan. Ketiga aktivitas tersebut saling berkaitan satu sama lain. Kedua, aspek historisitas. Manusia merupakan subjek sejarah, yang terdiri dari masa lalu, masa sekarang dan masa depan. Kesejarahan dalam filsafat tindakan Arendt, menekankan pada kehidupan kebaharuan. Hal ini berarti bahwa manusia selalu mengalami keterlahiran kembali. Keterlahiran akan membuka kemungkinan-kemungkinan baru. Ketiga, aspek sosialitas. Setiap manusia adalah unik. Masing-masing pribadi berbeda dengan pribadi yang lain. mereka hidup di dalam sebuah komunitas yang 
plural, sehingga dibutuhkan jalinan persahabatan dalam membangun kehidupan yang plural.

Filsafat Arendt telah berhasil menjawab persoalan pelanggaran HAM pada masa di bawah kekuasaan Nazi. Analisis Arendt terhadap persoalan tersebut menekankan pada kepribadian manusia yang memiliki kesadaran berpikir dalam menghadapi situasi yang cenderung otoriter. Analisis lain adalah adanya kemampuan manusia mengampuni, berjanji serta membangun persahabatan. Hal tersebut menginspirasi penulis untuk menjawab persoalan pelanggaran HAM tahun 1965-1966 di Indonesia. Pemahaman berdasarkan kesadaran berpikir, ampunan, janji dan persahabatan akan memutus siklus dendam, memulihkan ingatan sosial, dan menjamin terciptanya hak asasi setiap warga negara.

\section{DAFTAR PUSTAKA}

Abidin, Zainal, 2000, Filsafat Manusia: Memahami Manusia Melalui Filsafat Manusia, PT. Remaja Rosdakarya, Bandung.

Ardiastro, Andi, 2007, Rekonstruksi Wacana Dalam Rekonsiliasi Sosial Di Indonesia (Studi Terhadap Pembangunan Perdamaian Dalam Kasus Pelanggaran Berat Hak Asasi Manusia 1965), Tesis Program Studi Ketahanan Nasional Konsentrasi Perdamaian Dan Resolusi Konflik, UGM, Yogyakarta.

Arendt, Hannah, 1958, The Human Condition, The University of Chicago Press, London.
1961, Between Past And Future, The Viking Press, New York.

1964, Eichmann in Jerusalem, The Viking Press, New York.

York.

1970, On Violence, Harcourt Brace Jovanovich, New

1973, The Origins of Totalitarianism, diterjemahkan oleh Agus Nugroho, 1993, Yayasan Obor Indonesia, Jakarta.

1977, The Life of The Mind, Harcourt Brace and Company, New York.

(Author), Beiner Ronald (Ed), 1982, Lectures on Kant's 
Political Philosophy, The University of Chicago Press, Chicago.

Aristoteles, Nichomachean Etics, University Adelaide Library, Pdf.

Asdi, Endang Danuri, 1997, Imperatif Kategoris Dalam Filsafat Moral Immanuel Kant, Lukman Ofset, Yogyakarta.

Bagus, Lorenz, 2000, Kamus Filsafat, Gramedia, Jakarta.

Bakker, Anton, 2000, Antropologi Metafisik, Kanisius, Yogyakarta.

Bertens, Kees, 2001, Filsafat Kontemporer Prancis, Gramedia, Jakarta. 2002, Filsafat Barat Kontemporer Inggris-Jerman, Gramedia, Jakarta.

Bernstein, Richard, 2006, "Arendt on Thinking," dalam Dana Villa (ed), The Cambridge Companion to Hannah Arendt, Cambridge University Press, London.

Brunkhorst, Hauke, 2006, "Equality and Elitism in Arendt," dalam Dana Villa (ed), The Cambridge Companion to Hannah Arendt, Cambridge University Press, London.

Cahyadi, Haryanto, 2008, “Merawat Jiwa: Warisan Platon Dalam Tafsiran Patocka", dalam Basis Edisi November-Desember, Yayasan BPBasis, Yogyakarta

Canovan, Margaret, 2006, "Arendt's Theory of Totalitarianism: A Reassessment," dalam Dana Villa (ed), The Cambridge Companion to Hannah Arendt, Cambridge University Press, London.

Copleston, Frederick, 1971, A History of Philosophy Vol VI, Search Press, London.

D'entreves, Maurizio Passerin, 2006, "Arendt's Theory of Judgment," dalam Dana Villa (ed), The Cambridge Companion to Hannah Arendt Cambridge University Press, London.

Fic, Victor, 2005, Kudeta 1 Oktober 1965: Sebuah Studi Tentang Konspirasi, terjemahan dari bahasa Inggris oleh Rahman Zainuddin dkk, Obor, Jakarta.

Formn, Erich, 2000, Manusia Menurut Marx, Pustaka Pelajar, Yogyakarta.

Hadi, Hardono, 1989, A Whitehedian Reflection On The Human Person, 
Disertation Submitted in Partial Fulfillment of The Requirements for The Degree of Doctor of Philosophy in The Department of Philosophy at Fordham University, New York. 1996, Jatidiri Manusia Berdasarkan Filsafat Organisme Whitehead, Kanisius, Yogyakarta.

Hardiman, Budi, 2003, Heidegger dan Mistik Keseharian, Kanisius, Yogyakarta.

2007, "Watak Paradoksal Hak Asasi Manusia," dalam Basis Edisi Maret-April 2007, Yogyakarta. 2009, Demokrasi Deliberatif, Kanisius, Yogyakarta.

2010, “Komersalisasi Ruang Publik Menurut Hannah Arendt dan Jurgen Habermas" dalam Ruang Publik, Melacak "PartisipasiDemokratis" Dari Polis Sampai Cyberspace, Kanisius, Yogyakarta.

Haryatmoko, 2003, Etika Politik Dan Kekuasaan, Kompas, Yogyakarta.

2010, Dominasi Penuh Muslihat Akar Kekerasan dan Dominasi, Gramedia, Jakarta.

Heidegger, M, 1962, Being and Time, Harper and Row, New York.

Kant, Immanuel, 1952, Critique of Judgment, Oxford University Press, NewYork.

1959, Critique of Pure Reason, J. M. Dent and Sons Ltd, London.

Kohn, Jerome, 2006, "Freedom: The Priority of The Political," dalam Dana Villa(ed), The Cambridge Companion to Hannah Arendt, CambridgeUniversity Press, London.

Leahy, Louis, 2002, Kosmos: Tanda Keagungan Allah, Kanisius, Yogyakarta.

Letche, John, 2001, 50 Filsuf Kontempores Dari Strukturalisme Sampai Postmodernitas, terjemahan dari bahasa Inggris oleh Gunawan Admiranto, Kanisius, Yogyakarta.

Mill, John, 2005, On Liberty (Perihal Kebebasan), terjemahan dari bahasa Inggris oleh Alex Lanur, Yayasan Obor, Jakarta.

Nasution, Adnan Buyung, 1993, "Kata Pengantar" dalam Asal-Usul Totalitarianisme, Yayasan Obor, Jakarta. 
Poeze, Harry, 2011, Madiun 1948 PKI Bergerak, terjemahan dari bahasa Belanda oleh Hesri Setiawan, Pustaka Obor, Jakarta.

Sihotang, Kasdin, 2009, Filsafat Manusia: Upaya Membangkitkan Humanisme, Kanisius, Yogyakarta.

Siregar, M. R, 2007, Tragedi Manusia Dan Kemanusiaan, Resist Book, Yogyakarta.

Owens, Patricia, 2009, "Hannah Arendt," dalam Teori-Teori Kritis, terjemahan dari bahasa Inggris oleh Teguh Wahyu Utomo, Baca, Yogyakarta.

Sindhunata, 2007, "Politik Pengampunan," dalam Basis Edisi MaretApril 2007, Yogyakarta.

Snijders, Adelbert, 2004, Antropologi Filsafat Manusia (Manusia, Paradoks Dan Seruan), Kanisius, Yogyakarta.

Sudiarja, A, 2007, "Hannah Arendt Dan Mary McCarthy," dalam Basis Edisi Maret-April 2007, Yogyakarta.

Supadjar, Damarjati, 1993, Nawangsari, MW Mandala, Yogyakarta.

Russel, Bertrand, 2007, Sejarah Filsafat Barat (Kaitannya Dengan Kondisi Sosio- Politik Dari Zaman Kuno Hingga Sekarang), terjemahan dari bahasa Inggris oleh Sigit Jatmiko dkk, Pustaka Pelajar, Yogyakarta.

Supeli, Karlina, 2007, “Berpikir Bersama Hannah Arendt,” dalam Basis Edisi Maret-April 2007, Yogyakarta.

Tjahjadi, Simon Petrus, 2004, Petualangan Intelektual, Kanisius, Yogyakarta.

Tutu, Desmon, 2001, Tiada Masa Depan Tanpa Pengampunan, terjemahan dari bahasa Inggris oleh Triyoga Dharma Utami, Ciscore, Solo.

Undang-Undang Republik Indonesia Nomor 39 Tahun 1999 Tentang Hak Asasi Manusia.

Undang-Undang Republik Indonesia Nomor 27 Tahun 2004 Tentang Komisi Kebenaran Dan Rekonsiliasi.

Undang-Undang Republik Indonesia Nomor 26 Tahun 2000 Tentang Pengadilan Hak Asasi Manusia.

Villa, Dana, 2006, “Introduction: The Development of Arend's Political 
Thought," dalam The Cambridge Companion to Hannah Arendt, Cambridge University Press, London.

Weij, Van der, 2000, Filsuf-Filsuf Besar Tentang Manusia, terjemahan dari bahasa Belanda oleh Bertens, Kanisius, Yogyakarta.

Whitehead, 1978, Process And Reality, The Free Press, New York.

Wibowo, A. Setyo, 2010, “Kepublikan Dan Keprivatan Di Dalam Polis Yunani Kuno," dalam F. Budi Hardiman (ed), Ruang Publik, Melacak "Partisipasi Demokratis" Dari Polis Sampai Cyberspace, Kanisius, Yogyakarta.

2009, "Status Tubuh (Soma) Dalam Filsafat Platon," dalam Manusia Teka-Teki Yang Mencari Solusi, Kanisius, Yogyakarta.

William, Large, 2008, Heidegger's Being and Time, Edinburg University Press, Edinburg. 